\title{
Physiological performance of common bean seeds of the black commercial group under saline stress
}

Josiane Cantuária Figueiredo, Elson Junior Souza da Silva, Jorge Luiz Rodrigues Barbosa, Jéssica Mengue Rolim, Amanda Martins Silva, Lilian Vanussa Madruga de Tunes

Universidade Federal de Pelotas - UFPEL, RS. E-mail: josycantuaria@yahoo.com.br

\begin{abstract}
Saline stress is a condition that causes changes in physiological performance in several species and even in cultivars of the same species. Thus, this study aimed to evaluate the physiological performance of black bean cultivars to salt stress. A completely randomized experimental design was used in a factorial scheme with two cultivars (Mataço and BRS Paisano) and five osmotic potentials simulated with sodium chloride solutions (control $=0.0 ;-0.2 ;-0.4 ;-0.6$ and $-0.8 \mathrm{MPa}$ ), in four replications of 50 seeds per treatment. The variables related to germination, first germination count, germination speed index, and shoot length were evaluated. There were significant interactions $(p<0.05)$ for all variables analyzed. In general, it is concluded that the physiological performance of the seeds of black bean cultivars is affected under simulated saline stress by $\mathrm{NaCl}$ solution with an osmotic potential below $-0.2 \mathrm{MPa}$.
\end{abstract}

Keywords: Phaseolus vulgaris L.; sodium chloride; cultivars; germination.

\section{Desempenho fisiológico de sementes de feijão-comum do grupo comercial preto sob estresse salino}

\section{Resumo}

O estresse salino é uma condição que provoca alterações no desempenho fisiológico em diversas espécies e até mesmo em cultivares de uma mesma espécie. Assim, o objetivo deste estudo foi avaliar o desempenho fisiológico de sementes de cultivares de feijão-preto ao estresse salino. Utilizou-se o delineamento experimental inteiramente casualizado em esquema fatorial com duas cultivares (Mataço e BRS Paisano) e cinco potenciais osmóticos simulados com soluções de cloreto de sódio (testemunha $=0,0 ;$ 0,$2 ;-0,4 ;-0,6$ e -0,8 MPa), em quatro repetições de 50 sementes por tratamento. Avaliaram-se as variáveis relativas à germinação, primeira contagem da germinação, índice de velocidade de germinação e comprimento da parte aérea. Houve interações significativas $(p<0,05)$ para todas as variáveis analisadas. De maneira geral conclui-se que o desempenho fisiológico das sementes das cultivares de feijão preto são afetados sob estresse salino simulado por solução de $\mathrm{NaCl}$ com potencial osmótico inferior a -0,2 MPa.

Palavras-chave: Phaseolus vulgaris L.; cloreto de sódio; cultivares; germinação.

\section{Introdução}

Brazil is one of the largest producers and consumers of common beans (Phaseolus vulgaris L.) in the world (FAOSTAT, 2019). This fact is due to the importance of this culture as a protein food in the Brazilian population's diet. Among the various types of beans consumed and grown in the country, black beans occupy second place. The State of Rio Grande do Sul is among the largest national producers of black beans. 
However, South Brazil faces a problem with excess salts in the irrigation water, to which plants are submitted in these conditions during their development. In the Rio Grande do Sul, the water used for irrigation comes from rivers supplied by coastal lagoons, leading to the salinization of soils with inadequate drainage (HARTER et al., 2014).

The performance of plants in saline conditions is influenced by the osmotic and ionic effects, which promote changes in the metabolic activities of cells and the cell elongation process, affecting plant growth and, in extreme cases, can cause the organism to die as a whole (TAIZ; ZEIGER 2013). Ionic toxicity can also lead to a delay in the appearance of seedlings and even reduce the seeds' viability, as it affects the physiological and metabolic processes of the embryonic tissue, delaying the imbibition of the seeds and the elongation of the roots (ESTEVES; SUZUKI, 2008).

To minimize these problems, it is necessary to develop rapid techniques to test new cultivars to identify tolerant genotypes capable of surviving a particular stress type (BEINSAN et al., 2018). The germination of seeds exposed to different concentrations of salts is used as an indicator of species tolerant to salinity; thus, germination and vigor tests are useful to determine species' physiological responses under salt stress (DANTAS et al., 2005).

Given the above, this work aimed to evaluate black bean cultivars' physiological performance to salt stress.

\section{Material and methods}

The experiment was carried out at the Didactic Laboratory of Seed Analysis, belonging to the Graduate Program in Seed Science and Technology at the Federal University of Pelotas (FAEM / UFPel). Common bean seeds from the black commercial group, the harvest of 2018, produced by Embrapa Clima Temperado at Terras Baixa Station, in Capão do Leão / RS, were used.

The experimental design used was completely randomized, in a $2 \times 5$ factorial scheme, with four replications. The treatments consisted of two common bean cultivars from the black commercial group (Mataço and BRS Paisano) and five osmotic potentials (0; -0.2; -0.4; -0.6 and $-0.8 \mathrm{MPa}$ ) the zero potential represented the control, without stress, for which distilled water was used. The quantities of solutes used to prepare solutions of different osmotic potentials with sodium chloride $(\mathrm{NaCl})$ were $0 ; 2.5 ; 5.0 ; 7.5$, and $10 \mathrm{~g}$ of $\mathrm{NaCl} \mathrm{L}-1$.

To simulate salt stress, sodium chloride solutions $(\mathrm{NaCl})$ were prepared following the Van't Hoff equation (SALISBURY; ROSS, 1992), where $\Psi_{O S}=$ osmotic potential $(\mathrm{MPa}), \mathrm{C}=$ concentration (mol L -1), i = isotonic coefficient, $R$ = general gas constant $(0.0082 \mathrm{MPa}$ mol $-1 \mathrm{~K}-1)$ and $\mathrm{T}=$ temperature $(\mathrm{K})$.

The seeds' initial water content was previously determined by the oven method at $105 \pm 3{ }^{\circ} \mathrm{C}$ for 24 hours (BRASIL, 2009).

For the germination test, four replications of 50 seeds per treatment were used. The seeds of the cultivars were sown between three sheets of germitest paper in the form of rolls and moistened with formulated solutions of $\mathrm{NaCl}$, equivalent to 2.5 times the weight of the dry paper, to provide the osmotic potentials previously described. The rolls were placed in a germinator at a temperature of $25^{\circ} \mathrm{C}$. The evaluations were carried out on the fifth (first germination count) and on a ninth day after sowing. According to criteria established by the Regras para Análise de Sementes - RAS (BRASIL, 2009), the results were expressed in percentage of normal seedlings.

The germination speed index was calculated by adding the number of seeds germinated each day, divided by the number of days between sowing and germination, according to Maguire's formula (1962).

Only normal seedlings were considered when assessing the length of the aerial part. For this, a graduated ruler was used, and the results were expressed in $\mathrm{cm}$.

All variables were subjected to the Lilliefors test $(p<0.05)$ and the Bartlett test $(p<0.05)$ to verify normality and homogeneity, respectively.

The data were subjected to analysis of variance at the $5 \%$ probability and subsequent 
regression analysis. When significant, the effects of cultivars were studied by the $\mathrm{F}$ test at $5 \%$ of significance, and the effects of osmotic potentials were studied by regression analysis, choosing the appropriate models to represent them according to their biological behavior, the significance of the model coefficients, and the value of the determination coefficient $\left(R^{2}\right)$.

\section{Results and discussion}

According to the variance analysis (Table $1)$, there was a significant interaction between cultivars and the level of osmotic potential for all variables analyzed. Good experimental precision was observed, according to the criteria established by Pimentel-Gomes (1985). These statistical parameter results give reliability to the inferences to be made about the average performance of the cultivars concerning the salinities' levels.

Table 1. Summary of the variance analysis for the characteristics of the germinative performance of beans, cultivar Mataço, and BRS Paisano at different levels of saline stress induced by $\mathrm{NaCl}$ solution.

\begin{tabular}{lllccc}
\hline Variation source & DF & G\% & FGC\% & \multicolumn{1}{l}{ GSI } & \multicolumn{1}{l}{ SL } \\
\hline Cultivar (C) & 1 & $547.60^{* *}$ & $180.63^{* *}$ & $2.79 * *$ & $0.19^{\text {ns }}$ \\
Osmotic potentials (OP) & 4 & $14988^{* *}$ & $3848.40^{* *}$ & $113.7^{* *}$ & $288.5^{* *}$ \\
C* OP & 4 & $107.60^{* *}$ & $32.7^{* *}$ & $0.66^{* *}$ & $4.58^{* *}$ \\
Residue & 30 & 19.8 & 4.26 & 0.14 & 0.33 \\
\hline CV\% & & 9.8 & 9.6 & 9.6 & 10.42
\end{tabular}

Note: ${ }^{* *}$ Significant at the $1 \%$ probability level by the $\mathrm{F}$. ns test: not significant.

$\mathrm{DF}=$ Degrees of freedom; CV\%= coefficient of variation; $\mathrm{G} \%=$ germination; FGC\%= First germination count; GSI= Germination speed index; $\mathrm{SL}=$ shoot length.

When evaluating the germinative performance and the vigor of the seeds (first germination count and germination speed index), in general, it was found that the cultivar BRS Paisano presented higher average values of germination and vigor. The cultivar BRS Paisano showed greater resistance to stress conditions up to $-0.4 \mathrm{MPa}$ compared to the cultivar Mataço
(Table 2). However, it is observed that up to the 0.2 potential, the seeds of the two cultivars studied showed germination values above $70 \%$, meeting the minimum standard recommended for the commercialization of basic bean seeds (BRASIL, 2013). 
Table 2. First germination count, germination, seed germination speed index of black bean cultivars at different saline stress levels induced by $\mathrm{NaCl}$ solution.

\begin{tabular}{|c|c|c|c|c|c|}
\hline \multirow[b]{2}{*}{ Cultivar } & \multicolumn{5}{|c|}{ Osmotic potential (MPa) } \\
\hline & 0 & -0.2 & -0.4 & -0.6 & -0.8 \\
\hline & \multicolumn{5}{|c|}{ First germination count (\%) } \\
\hline Mataço & $42 \mathrm{~b}$ & $39 \mathrm{~b}$ & $23 \mathrm{~b}$ & $0 \mathrm{~b}$ & $0 \mathrm{~b}$ \\
\hline \multirow[t]{2}{*}{ BRS Paisano } & $48 \mathrm{a}$ & 46 a & $31 \mathrm{a}$ & $0 \mathrm{~b}$ & $\mathrm{Ob}$ \\
\hline & \multicolumn{5}{|c|}{ Germination (\%) } \\
\hline Mataço & $83 \mathrm{a}$ & $77 \mathrm{~b}$ & $50 \mathrm{~b}$ & $\mathrm{Ob}$ & $0 \mathrm{~b}$ \\
\hline \multirow[t]{2}{*}{ BRS Paisano } & $93 \mathrm{a}$ & $91 \mathrm{a}$ & $63 \mathrm{a}$ & $0 \mathrm{~b}$ & $0 \mathrm{~b}$ \\
\hline & \multicolumn{5}{|c|}{ Germination speed index (IVG) } \\
\hline Mataço & $7.1 \mathrm{~b}$ & $6.5 \mathrm{~b}$ & $4.1 \mathrm{~b}$ & $0 \mathrm{~b}$ & $0 \mathrm{~b}$ \\
\hline BRS Paisano & $8.1 \mathrm{a}$ & $7.9 \mathrm{a}$ & $6.8 \mathrm{a}$ & $0 \mathrm{~b}$ & $0 \mathrm{~b}$ \\
\hline
\end{tabular}

Note: Averages followed by the same letter in the column do not differ by the $\mathrm{F}$ test at $1 \%$ significance.

From the effects of each cultivar's osmotic potentials, it was possible to observe that the results of germination, first germination count, and germination speed index of both species adjusted to a negative linear regression model (Figures $1 \mathrm{~A}, \mathrm{~B}$, and $\mathrm{C}$ ).

The control treatment ( $0 \mathrm{MPa}$ ) obtained the highest percentages of germination and vigor. However, the seeds' physiological performance was progressively reduced as the osmotic potentials became more negative, indicating the sensitivity of the seeds of the cultivars to the stress submitted.

Figure 1. Graphical representation of the first germination count (A), germination (B), and Germination speed index (C) of black bean cultivar seeds at different levels of saline stress induced by $\mathrm{NaCl}$ solution.

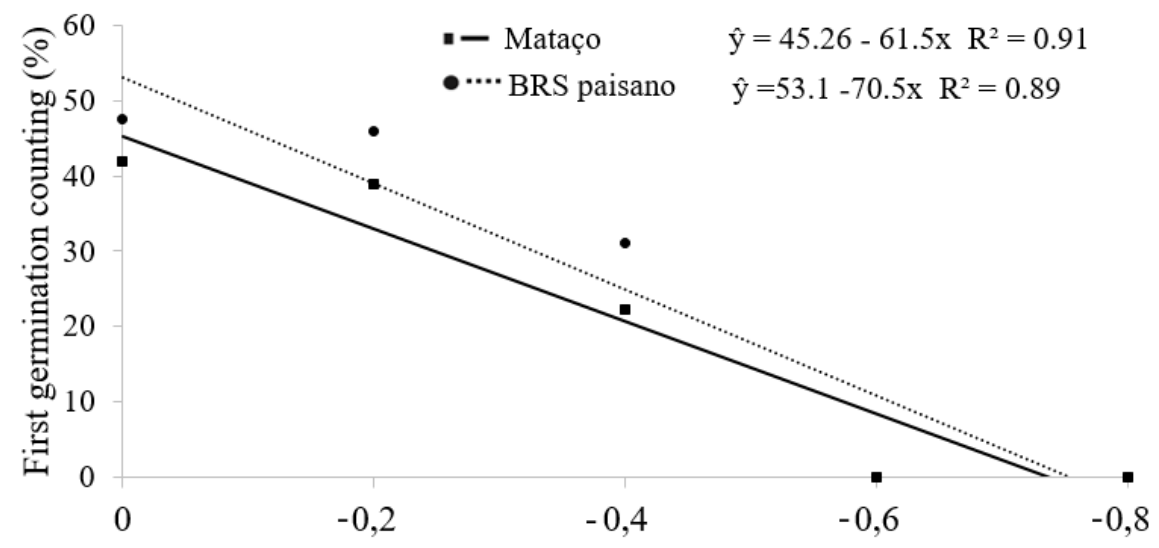

Osmotic potential (Mpa) 

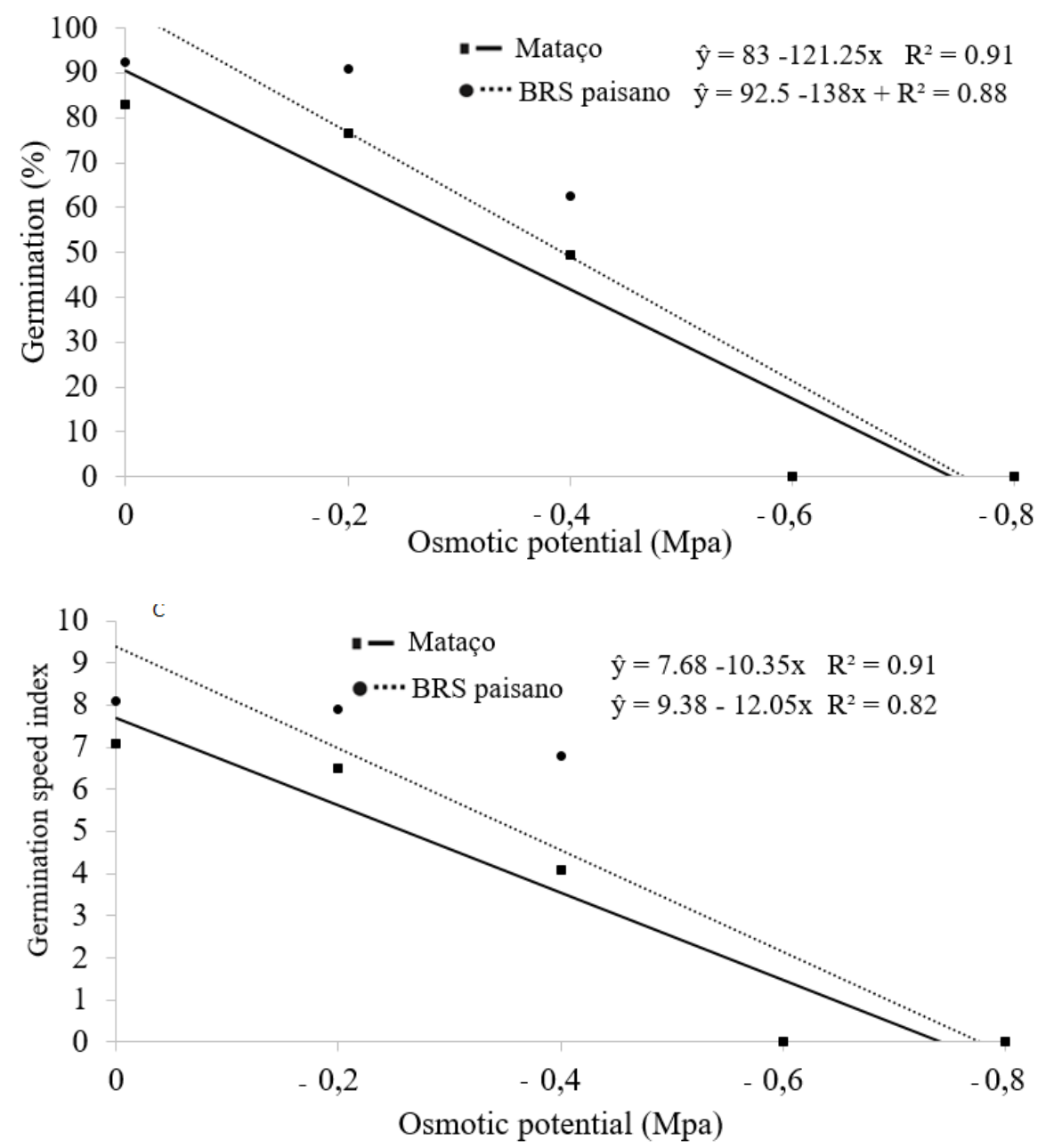

Similar results were found by Coelho et al. (2017), evaluating seeds of different cowpea cultivars, showed that in the potential $0 \mathrm{MPa}$, the percentage of seed germination was close to $100 \%$, decreasing as the osmotic potentials became more negative.

The reduction in germination and vigor of the seeds in negative osmotic potential may be due to the increase in phase III of the imbibition process. According to Bewley's three-phase standard, Black (1994), the seed's intense water uptake and root growth occur at this stage. Besides, a high concentration of salts in cells can also deactivate enzymes, inhibit protein synthesis and prevent seed germination (TAIZ; ZEIGER, 2013). The reduction in germination can also be attributed to the physiological drought produced. When there is an increase in the concentration of salts in the germination substrate, there is a decrease in the osmotic potential and, consequently, a reduction in the water potential (CAVALCANTE et al., 2019).

Literature results show that salinity harms the percentage of the physiological potential of various cultures, such as Oryza sativa L. (CAVALCANTE et al., 2019), Pisum sativum (PEREIRA et al., 2020), Vigna unguiculata L. (GOMES FILHO et al., 2019), and Salvia hispanica (STEFANELLO et al., 2020).

Regarding the shoot length variable, it was observed that there was no significant effect between cultivars up to $-0.2 \mathrm{MPa}$. However, at the -0.4 MPa potential, the cultivar Mataço was superior to the cultivar BRS Paisano (Table 3). This result can be attributed to the genetic makeup of the cultivar itself. 
Table 3. Shoot length of black bean cultivars at different levels of saline stress induced by $\mathrm{NaCl}$ solution.

\begin{tabular}{llllll}
\hline & \multicolumn{5}{c}{ Osmotic potential (MPa) } \\
\cline { 2 - 6 } Cultivar & $\mathbf{0}$ & $-\mathbf{0 . 2}$ & $-\mathbf{0 . 4}$ & $-\mathbf{0 . 6}$ & $-\mathbf{0 . 8}$ \\
\cline { 2 - 6 } Mataço & $14.3 \mathrm{a}$ & $10.5 \mathrm{a}$ & $4.9 \mathrm{a}$ & $0 \mathrm{~b}$ & $0 \mathrm{~b}$ \\
BRS Paisano & $14.5 \mathrm{a}$ & $9.2 \mathrm{a}$ & $3.3 \mathrm{~b}$ & $0 \mathrm{~b}$ & $0 \mathrm{~b}$ \\
\hline
\end{tabular}

Note: Averages followed by the same letter in the column do not differ by the $\mathrm{F}$ test at $1 \%$ significance.

Analyzing the shoot length (Figure 2), by adjusting the regression lines for the two cultivars, it was observed that they showed a similar trend in the established treatments. In the seedlings of the control treatment, the values observed between the two cultivars were higher. However, with the increase in $\mathrm{NaCl}$ concentrations, there was a reduction in the shoot length (Figure 2).

Figure 2. Graphical representation of the shoot length of black bean cultivars at different saline stress levels induced by $\mathrm{NaCl}$ solution.

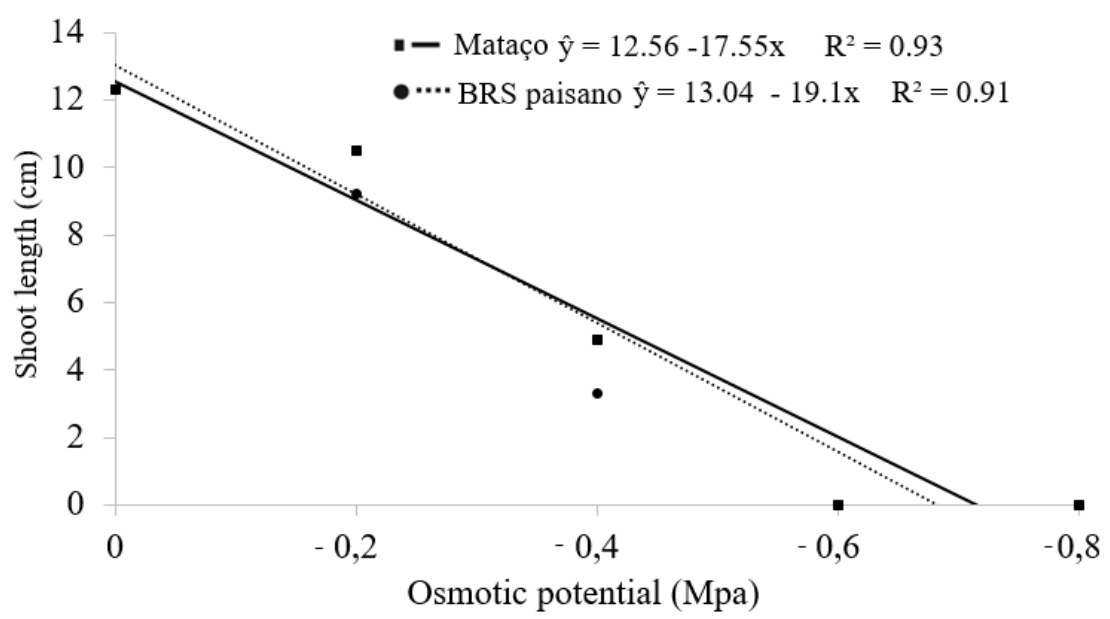

Similar results were obtained by Pereira et al. (2020), who reported that saline stress caused a reduction in the pea seedling epicotyl length. This reduction is related to the low water availability and the high level of salinity in the substrate. Besides, the high salt level causes changes in the plant's ability to absorb, transport, and use the ions necessary for its growth. It reduces the rate of metabolic assimilation, the activity of enzymes responsible for respiration and photosynthesis, thus restricting the attainment of energy for the growth and differentiation of cells in tissues, reducing the elongation of the embryonic axis (NOBRE et al., 2010). The seed starts to germinate in ideal conditions. However, with a low amount of water, the embryonic axis's growth may be impeded, resulting in less development and shorter seedling length.

\section{Conclusion}

The cultivars' seeds showed different behavior regarding the conditions of salt stress, and the cultivar BRS Paisano was more tolerant to salt stress.

The seeds of black bean cultivars submitted to the $\mathrm{NaCl}$ solution with potentials lower than $-0.2 \mathrm{MPa}$ have a germination percentage below $70 \%$.

This information is useful in making decisions about these cultivars' production process about the growing region's appropriate choice 


\section{Acknowledgment}

This work was carried out with the support of the Coordenação de Aperfeiçoamento de Pessoal de Nível Superior -Brasil (CAPES)Financing code 001.

\section{References}

BEINSAN, C.; SUMALAN, R.; VATCA, S. The Influence of Osmotic Stress on Physiological and Biochemical Indices at Garlic (Allium sativum L.) Local Populations. Bulletin UASVM Food Science and Technology, v.72, n.2, p.172-178, 2018. http://dx.doi.org/10.15835/buasvmcnfst:2018.0006v

BEWLEY, J.D.; BLACK, M. Seeds: Physiology of development and germination. 2. ed. New York: Springer. 1994. https://doi.org/10.1007/978-14899-1002-8

BRASIL. Ministério da Agricultura, Pecuária e Abastecimento. Instrução Normativa no 45, de 17 de setembro de 2013. Estabelece os padrões de identidade e qualidade para produção e comercialização de sementes de feijão, disposto em anexo. Diário Oficial da República Federativa do Brasil, 2013. p. 13-14.

BRASIL. Ministério da Agricultura, Pecuária e Abastecimento. Secretaria de Defesa Agropecuária. Regras para análise de sementes. Brasília: MAPA, 2009.

CAVALCANTE, J. A.; REOLON, F.; MORAES, C.L. DE.; TERNUS, R.M.; SILVA, R.N.O.; MARTINS, A.B.N.; MORAES, D.M. Potencial fisiológico de sementes de duas cultivares de arroz em resposta ao stresse salino. Revista de Ciências Agrárias, v.42, n.1, p.181-190. 2019. http://dx.doi.org/10.19084/RCA17279

COELHO, D.S.; SILVA, J.A.B.; NASCIMENTO, R.L.; COSTA, J.D.S.; SEABRA, T.X. Germinação e crescimento inicial de variedades de feijão caupi submetidas a diferentes concentrações salinas.

Revista Verde de Agroecologia e Desenvolvimento Sustentável, v.12, n.2, p.261-
266,

2017.

http://dx.doi.org/10.18378/rvads.v12i2.4419

DANTAS, B.F.; RIBEIRO, L. S.; ARAGÃO, C.A. Physiological response of cowpea seeds to salinity stress. Revista Brasileira de Sementes, v.27, n.1, p.144-148, 2005. http://dx.doi.org/10.1590/S0101-

31222005000100018

ESTEVES, B.S.; SUZUKI, M.S. Efeito da salinidade sobre as plantas. Oecologia Australis, v.12, n.4, p.662-679, 2008.

FAOSTAT. Crops. Disponível em: http://www.fao.org/faostat/en/\#data/QC.

Acesso em: 17 fev. 2019.

GOMES FILHO, A.; RODRIGUES, E.N.; RODRIGUES, T.C.; SANTOS, V. J.N.; ALCÂNTARA, S,F.; SOUZA, F.N. Estresse hídrico e salino na germinação de sementes de feijão-caupi cv. BRS Pajeú. Revista Colloquium Agrariae, v.15, n.4, p.60-73, 2019. https://revistas.unoeste.br/index.php/ca/article/ view/2741

HARTER, L.S.H.; HARTER, F.S.; DEUNER, C.; MENEGHELLO, G.E.; VILELLA, F.A. Salinidade e desempenho fisiológico de sementes e plântulas de morango. Horticultura Brasileira, v.32, n.1, p.80-85, 2014. http://dx.doi.org/10.1590/S010205362014000100013

MAGUIRE, J.D. Speed of germination aid in selection and evaluation for seedling emergence and vigor. Crop Science, v.2, p.176-77, 1962. http://dx.doi.org/10.2135/cropsci1962.0011183X $000200020033 x$

NOBRE, R.G.; GHEYI, H.R.; CORREIA, K.G.; SOARES, F.A. L.; ANDRADE, L.O. Crescimento e floração do girassol sob estresse salino e adubação nitrogenada. Revista Ciência Agronômica, v.41, n.3, p.358-365, 2010. https://doi.org/10.1590/S1806-

66902010000300006 
PEREIRA, I.C.; CATÃO, H.C.R.M.; CAIXETA, F. Seed physiological quality and seedling growth of pea under water and salt stress. Revista Brasileira de Engenharia Agrícola e Ambiental, v.24, n.10, p.95-100, 2020. http://dx.doi.org/10.1590/18071929/agriambi.v24n2p95-100

PIMENTEL-GOMES, F. Curso de estatística experimental. 11. ed. Piracicaba: Esalq, 1985.

SALISBURY, F.B.; ROSS, C.W. Plant physiology. Belmont, USA: Wadsworth Publishing Company, 1992.

STEFANELLO, R.; VIANA, B.B.; GOERGEN, P.C. H.; NEVES, L. A.S.; NUNES, U.R. Germination of chia seeds submitted to saline stress. Brazilian Journal of Biology, v.80, n.2, p1-5, 2020. https://doi.org/10.1590/1519-6984.192140

TAIZ, L.; ZEIGER, E. Fisiologia vegetal. Porto Alegre: ARTMED, 2013. 